\author{
Седікова I.O. \\ кандидат економічних наук, доцент \\ кафредра менеджменту та логістики \\ Одеська національна академія харчових технологй \\ вул. Канатна, 112, м. Одеса, Україна, 65039 \\ E-mail: irina-sedikova@rambler.ru
}

\title{
УМОВИ ЕКСПОРТУ ЗЕРНОВИХ ВАНТАЖІВ УКРАЇНИ В НОВИХ РЕАЛІЯХ
}

Проведено дослідження стану розвитку та відродження річкового судноплавства України. Зроблено висновки та пропозиції щодо необхідності зміни діючого законодавства, необхідності розвитку внутрішньої водної інфраструктури. Встановлено та доведено, що $є$ нагальна потреба у приведенні тарифного навантаження держави на річкові перевезення до економічно обґрунтованого рівня, створення рівних конкурентних умови для роботи на річковому транспорті.

Ключові слова: зерновий ринок, експорт, зернова логістика, водні шляхи, морські та річкові порти.

Постановка проблеми та їі зв'язок з важливими науковими та практичними завданнями. Агросектор України 3 його базовою складовою сільським господарством - $\epsilon$ системоутворюючим в національній економіці, формуючи фактори суверенності держави - продовольчу, економічну, екологічну та енергетичну безпеку держави, забезпечує розвиток технологічно пов'язаних галузей економіки, утворює ринок сільгосппродукції і продовольства. Україна $\epsilon$ лідером в експорті цілої низки сільгоспкультур (передусім зернових культур) і рослинних жирів (зокрема, соняшникової олії). Вітчизняний агросектор зі значними експортним потенціалом може стати рушієм розвитку національної економіки, надаючи імпульс інвестиційному, технологічному та соціальному піднесенню України.

Аналіз останніх публікацій 3 проблеми. Значним внеском у розробку проблеми формування ефективного зернового ринку є наукові дослідження російських вчених, зокрема, О. Скринік, О. Сизова, А. Михайлева, А. Корбута; вчених із Казахстану С. Хасенова, А. Бісенбаєва, Є. Гана, У. Дуалета, А. Куришбаєва, які провели комплексне дослідження виробництва та ринку зерна по цих країнах і розробили заходи щодо його вдосконалення. Розвиток зернового ринку України знаходиться у центрі уваги таких вітчизняних дослідників, як М.В.Присяжнюк, М.Д. Безуглий, С.М. Кваша, А.В. Розгон, П.Т. Саблук, О.В. Нікішина [4], I.I. Савенко [5-6] та інших вчених. Фактори формування цінових тенденцій на зерновому ринку України на сучасному етапі розгля- даються у дослідженнях Ю.Я. Лузана [3], О.В. Боднара [1], О.М. Шпичака, І.В. Кобути [2], Ю.С. Воскобійник та інших. Поряд із цим назріла потреба подальшого аналізу й опрацювання досліджень у контексті змін експорту зернових вантажів в нових умовах.

Формулювання цілей дослідження. Україна доводить, що готова, незважаючи на те, що відбуваються в країні, виконувати взяті на себе перед міжнародними партнерами зобов'язання. Зокрема, це стосується експорту сільськогосподарської продукції. Готовності інфраструктури зернового ринку України забезпечувати зростаючі обсяги експорту сільгосппродукції та викликам сьогодення присвячене дане дослідження.

Виклад основних результатів та їх обгрунтування. Україна $є$ одним 3 основних світових виробників зерна, а в 2013/14 МР міцно закріпилася серед лідерів 3 експорту зернових. Так, наприклад, за останнє десятиліття частка експортованого зерна зросла з 27\% в 2004/05 МР до 52\% від загального обсягу виробництва зерна, прогнозованих у 2013/14 МР. При цьому, для ринку кукурудзи частка експорту складає $66 \%$. Це дозволяє констатувати експортну орієнтацію українського зернового ринку, при якій з 63 млн. тонн виробленого в 2013 р. зерна близько 32,5 млн. тонн було експортовано. За даними Мінагропроду, за 2013/14 МР з України було експортовано близько 32,5 млн. тонн зерна, 20,1 млн. тонн кукурудзи і 2,5 млн. тонн ячменю. Саме цей рекордний обсяг дозволив Україні замкнути трійку лідерів серед світових експортерів зернових в минулому сезоні (табл.1).

Таблиця 1

ТОП світових експортерів у 2013/14 МР

\begin{tabular}{|c|c|c|}
\hline Країна & Обсяг експорту, млн. тонн & Частка, \% \\
\hline Великобританія & 85,3 & 27 \\
\hline ЄС & 38,2 & 12 \\
\hline Україна & 32,2 & 8 \\
\hline Канада & 26,5 & 8 \\
\hline Австралія & 26,4 & 8 \\
\hline Росія & 24,9 & 27 \\
\hline Інші & 86,0 & \\
\hline Всього & 319,5 & \\
\hline
\end{tabular}

Джерело: [7, с. 8-14] 
Те, що українська зернова логістика зуміла обробити такі обсяги, стало свого роду перевіркою для внутрішньої пропускної здатності та портової логістики в Україні. У листопаді-грудні 2013 р. через портові зернові термінали було перевалено 5 млн. тонн, що, на думку учасників ринку, було нереальним у порівнянні з минулими сезонами, коли рекорд перевалки становив близько 3,8 млн. тонн. Варто відзначити деякі технічні фактори, які ускладнювали пересування зерна по логістичному ланцюгу. На думку Ю. Скічко [7, с. 19], однією з таких проблем є незлагоджена робота деяких терміналів, через що не завжди можна було отримати підтвердження необхідної кількості вагонів, що поставляються на розвантаження. Ще одним відмітним фактом сезону стала зміна зернової логістики України за рахунок анексії Криму. Безумовно, головним викликом сьогодення $є$ перенаправлення вантажних потоків зерна 3 портів Криму в порти материкової України. Однак експерти та учасники зернового ринку свідчать, що втрата кримських портів не зробить істотного впливу на темпи експорту зернових. Тому є кілька причин.

По-перше, Україна вже експортувала велику частину запланованого обсягу зернових та олійних вантажів. Так, згідно 3 даними ІА «АПК-Інформ», в липні-квітні 2013/14 МР експорт зерна з України склав 28,71 млн. тонн (+ $41 \%$ до рівня за аналогічний період сезону - 2012/13 р.) при експортному потенціалі в 31,1 млн. тонн, олійних - 3,2 млн. тонн (+24\%) при потенціалі в 3,63 млн. тонн [8].

По-друге, обсяги відвантажень зерна з портів Криму по відношенню до загального обсягу експорту країни є незначними. Так, за словами керівника служби бізнес-проектів ІА «АПК-Інформ» Р. Рибчинського, частка перевалки зернових через термінали Криму складає до 5\% [8]. Слід відзначити, що розподіл відвантажень зернових за портами, згідно з даними аналітиків IA «АПК-Інформ», був таким: через порти Одеської області було відвантажено 1,23 млн. тонн (58\% від загального обсягу перевалки), Миколаївській області - 552 тис. тонн (26\%), Херсонській 157 тис. тонн (7\%), Запорізькій - 101,3 тис. тонн

(5\%), Донецькій - 88,3 тис. тонн (4\%) [7, с. 22]. Отже, у 2014/15 МР Україні ніщо не заважає виконати експортну програму. Що ж стосується перспектив на майбутне, то, як зазначив В. Романченко, на сьогоднішній день потужності з перевалки зернових в морських портах України становлять, за різними оцінками, від 45 до 50 млн. тонн. Крім того, він повідомив, що, згідно із затвердженими планами розвитку морських портів України, Іллічівський порт має намір збільшити потужності з перевалки зернових і зернобобових вантажів майже на 12 млн. тонн, Південний порт - на 21 млн. тонн, Одеський - на 5 млн. тонн. Що стосується Одеського порту, то завдяки реалізації інвестиційних проектів пропускна здатність збільшиться до 10-12 млн. тонн зернових вантажів проти 1-8 млн. тонн [7, с. 15]. У першу чергу, це спільний з «Бруклін-Київ» проект. Будівництво зернового терміналу потужністю 4 млн. тонн реалізовано на 50\%, зерновий термінал, розташований на четвертому причалі укомплектовано на 90\%. Однак, якщо говорити про малотоннажні експортні партії, то загострення політичної ситуації в Україні викликає побоювання учасників ринку щодо можливості реалізації відвантажень, це визвано, по-перше, невизначеністю умов проходження судами Керченської протоки, яка повністю знаходиться під контролем Росії. «Закриття Керченської протоки і зупинка терміналів завдають серйозного удару по експортерах борошномельної продукції та висівок. Замістити ці обсяги можна тільки через неглибоководні порти - через Херсон, Миколаїв. На жаль, порти Одеси навряд чи будуть виступати допоміжною силою в такій ситуації, тому що вони будуть брати на себе обсяги великотоварних партій зерна, які йшли на Севастополь», - вважає Р. Рибчинський [8]. Можливі проблеми портів Азовського моря, зокрема, ускладнення проходу суден через Керченську протоку, можуть сприяти розвитку портової інфраструктури Одесько-Дунайського регіону, можливе будівництво річкових терміналів у портах Чорного моря у разі переформатування логістичних потоків українських зернових вантажів. Пропозиції щодо розвитку річкової логістики наведено у таблиці 2.

Таблиця 2

Розвиток річкової логістики

\begin{tabular}{|c|c|}
\hline Перешкоди & Пропозиції \\
\hline $\begin{array}{l}\text { Обмеження габаритів суднового ходу у районі Дніпродзержинсь- } \\
\text { ка }\end{array}$ & Днопоглиблення судового ходу річок. \\
\hline Недосконалість законодавчої бази & $\begin{array}{l}\text { Прийняття комплексу законопроектів, сти- } \\
\text { мулюючих розвиток галузі; оновлення } \\
\text { Статуту внутрішнього водного транспорту } \\
\text { Союзу РСР; Закон “Про річкові порти". }\end{array}$ \\
\hline $\begin{array}{l}\text { Бюрократичні моменти у будівництві та експлуатації гідротехні- } \\
\text { чних споруд }\end{array}$ & $\begin{array}{l}\text { Спрощення процедури отримання дозволів } \\
\text { на будівництво гідротехнічних споруд. }\end{array}$ \\
\hline Тяжкий стан існуючого флоту & \multirow[t]{2}{*}{ Податкові канікули на 5 років. } \\
\hline Несприятливі умови інвестування для будівництва нового флоту & \\
\hline $\begin{array}{l}\text { Обмеження роботи суден під іноземним прапором у внутрішніх } \\
\text { територіальних водах України: } \\
\text { - необхідність отримання дозволу; } \\
\text { - обмежена кількість перевантажувальних причалів України, що } \\
\text { можуть працювати з суднами під іноземним прапором (9 портів). }\end{array}$ & $\begin{array}{l}\text { Зняття обмежень входу торгових суден під } \\
\text { іноземним прапором, як до річкових по- } \\
\text { ртів, так і до інших причалів. }\end{array}$ \\
\hline
\end{tabular}


Транспортний потенціал річок України (Дніпро и Південний Буг) величезний. Якщо порівняти вартість перевезень річковим, залізничним і автотранспортом, то переваги першого вражають: від \$ 12,5 за тонну (у порівнянні з \$28 за тонну при перевезеннях залізничним і \$ 21 - автотранспортом. Ми не можемо не замислюватися над тим, яким чином відродити судноплавство на Дніпрі та на інших внутрішніх водних шляхах країни (ВВШ), так як перевезення в порівнянні з 1990 роком (66 млн. тонн) до 4 млн. тонн впали в 19 разів.

Основний перевізник на річковому транспорті України, АСК «Укррічфлот», задекларував загальний дедвейт в 80 тис. тонн, з яких трюмних (тих, які можуть перевозити зернові) тільки 25 тис. тонн. Задекларована АСК «Укррічфлот» можливість перевезення 600 тис. тонн трюмних вантажів на рік не дозволить перевезти річкою і 1\% врожаю зернових України [9]. Іншим важливим перевізником зернових вантажів річкою є ТОВ СП «НІБУЛОН», дедвейт флоту якого становить 131080 тонн, який декларує перевезення 1,3-1,5 млн. тонн на рік, але перевозить тільки свій вантаж і не може задовольняти попит інших підприємств на перевезення внутрішнім водним транспортом. При критичній нестачі пропозиції, неконкурентних умовах i, як наслідок, дорогого фрахту, рішенням на першому етапі може стати залучення до роботи на ВВШ малотоннажного флоту під іноземним прапором. Це створить реальну конкуренцію, стабілізує тарифи, що, в свою чергу, призведе до збільшення вантажообігу рікою. Варто відзначити, що перевезення річковим транспортом становить лише $3 \%$ всіх відправлених на експорт зернових - $36 \%$ та $61 \%$ перевозиться автомобільним транспортом і залізницею відповідно. Задовольнити існуючу нестачу пропозиції флотом під прапором інших держав заважають пільги суднам під українським прапором та існуючий порядок отримання одноразового дозволу, ліцензій для роботи на ВВШ для суден під іноземним прапором (рис. 1).

Далі. Портові збори. Так як різниця між розміром портових зборів, які стягуються судами в каботажних рейсах та зборами, які стягуються судами в іноземних рейсах, становить близько 10 разів, або до 7 доларів на тонну, використання малотоннажного флоту для роботи на короткому плечі (країни Чорного моря і Середземномор'я) є неефективним економічно і майже не використовується вітчизняними вантажовласниками, незважаючи на перспективність роботи на ринках вищевказаних регіонів.

Далі. Лоцманська проводка. Необгрунтовано високі тарифи на лоцманську проводку суден по ВВШ $є$ основною стримуючою складовою для відновлення судноплавства на Дніпрі та інших річках України. Лоцманський збір є найбільшим за розміром серед зборів дисбурсментських рахунків (англ. disbursment account - документ, який пред'являється портовим агентом та відображає витрати (податки, збори, роботи з обслуговування судна), зроблені ним за рахунок судновласника під час перебування судна в порту стоянки; скріплюється підписом капітана судна) [10]. Без зміни підходу до лоцманського збору не можна говорити про перспективи судноплавства від Херсона до Києва і вище, в Білорусь, виходячи 3 того що зі збільшенням довжини рейсу критично збільшується вартість лоцманського збору на тонну вантажу. Лоцманський збір повинен бути якщо не повністю знівельований, то зведений до мінімуму шляхом встановлення обов'язкової лоцманської проводки тільки на тих ділянках ВВШ, де дійсно існує небезпека або потреба в лоцманській проводці, а саме на ділянках від міста Дніпропетровськ в місто Кременчук до закінчення днопоглиблювальних робіт.

Розведення мостів. Згідно ст. 99 Статуту залізниць України [11], судновласник компенсує власнику моста вартість розводки на договірній основі. Вартість розведення мостів варіюється від 984 доларів США за розводку Кременчуцького мосту до 1968 доларів США за розведення Дніпропетровського мосту.

Шлюзування. Вартість шлюзування регулюється Постановою Кабінету Міністрів України від 15.04.2009 р № 350 [13] та встановлює плату за проходження шлюзів на ВВШ, оплата надходить до фонду підтримки та реконструкції шлюзів ДП «Укрводшлях». Слід відзначити, що стаття шлюзування буде збільшена, і навантаження на судновласника $i$, як результат, на вантажовласника, зросте; ціна фрахту збільшиться, незважаючи на те, що навіть за умови збільшення ставок шлюзування і скасування пільг для українського перевізника, надходження від зборів не забезпечать не те що реконструкції, а й поточного ремонту шлюзів, про що неодноразово говорили самі представники Міністерства інфраструктури України та ДП «Укрводшлях». Виходом із ситуації бачимо всебічну підтримку позиції про необхідність переведення шлюзів на часткове фінансування підприємствами енергетичного комплексу, згідно практики Китайської Народної Республіки (КНР), де шлюзи і гідроелектростанції складають єдиний майновий комплекс i фінансуються 3 адресних відрахувань при продажу електроенергії компаніями, які здійснюють іiі збут і виробництво.

Згідно з чинним законодавством, всі роботи 3 підтримки суднового ходу, ремонту, експлуатації та обслуговування гідротехнічних споруд здійснюються силами і за рахунок спеціально створеного 3 цією метою ДП «Укрводшлях». ДП «Укрводшлях» не вистачає фінансування на виконання необхідних робіт 3 підтримки суднового ходу та поточного ремонту шлюзів, що призводить до обміління водних артерій України. Вирішити цю проблему можливо за рахунок іноземних інвестицій, в першу чергу, країн СС в рамках програм «Traceca» та програми TEN-T (програма спрямована на розвиток транспортної інфраструктури держав-членів СС та сусідніх країн для забезпечення безперешкодного руху пасажирів та товарів по території всього континенту). 


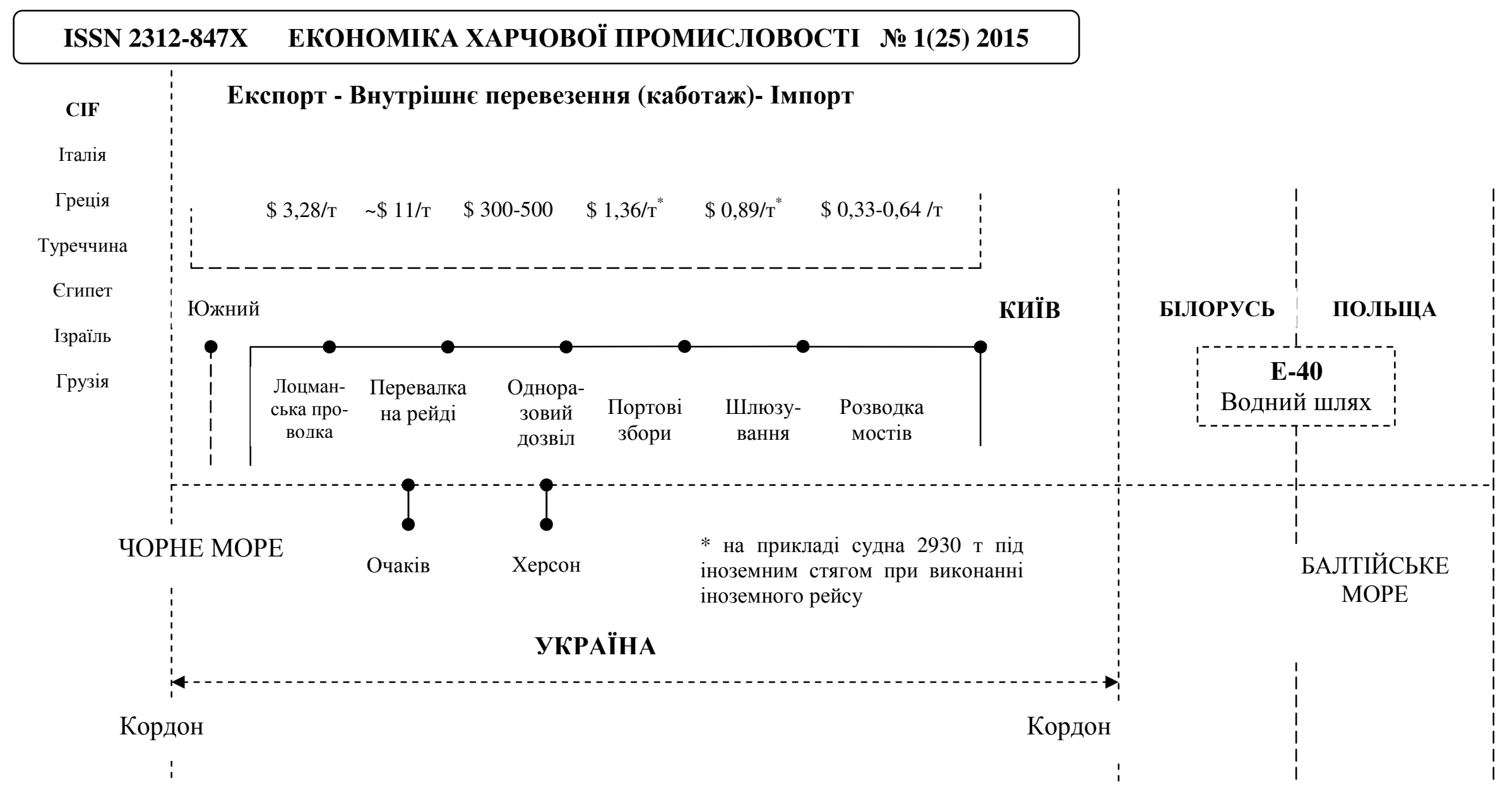

Рис. 1. Проблемні питання на внутрішніх водних шляхах України 
Програма «Вісла-Буг-Дніпро» вже існує, i, на даний момент, здійснюється тендер на розробку проекту. 90\% вартості проекту буде оплачено з бюджету ЄC. Для створення механізму інвестування коштів у ВВШ України як міжнародними фінансовими інститутами, так і приватними інвесторами, необхідно реформувати ДП «Укрводшлях» в структуру, яка може отримувати кошти у вигляді інвестицій під державні гарантії, взявши за приклад Державне агентство автомобільних доріг України, яке отримало кошти від Європейського банку реконструкції та розвитку на будівництво нових автомобільних шляхів.

Висновки та перспективи подальших досліджень. Проведене дослідження розвитку та проблем річкового судноплавства дало змогу зробити такі висновки та пропозиції:

1. Для відродження судноплавства необхідні законодавчі зміни, які зможуть підштовхнути розвиток внутрішньої водної інфраструктури, привести тарифне навантаження держави на річкові перевезення до економічно обгрунтованого рівня, створити рівні конкурентні умови для роботи на річковому транспорті.

2. Порівняти правовий статус та економічні умови судна під українським та іноземним прапорами при роботі на ВВШ і скасувати Наказ Міністерства інфраструктури України від 09.11.2012 р. № 665 «Про затвердження Порядку видачі одноразових тимчасових дозволів на захід до річкових портів України суднам під прапорами держав, з якими не укладено міжнародні договори про судноплавство на внутрішніх водних шляхах» [12].

3. Знизити тарифний тиск на перевізників, шляхом зрівнювання розміру портових зборів для іноземних рейсів до рівня каботажних рейсів, а також зниження ставок портових зборів.

4. Вважаємо за доцільне введення графіка розводки кожного окремого моста, згідно з яким зазначені мости повинні розводитись в певний час, i проходження моста в цей певний час для суден $є$ безкоштовним, та встановлення економічно обгрунтованих ставок розводки мостів у разі такої необхідності поза графіком.

На даний момент, невизначеність правого статусу портів, терміналів, земель річкового транспорту, гідротехнічних споруд, прав та обов'язків перевізників, порту і вантажовласника нівелює інвестиційну привабливість річкового транспорту.

\section{Література}

1. Боднар О. В. Формування цінових тенденцій на зерновому ринку України / О. В. Боднар // Наук. вісн. Нац. ун-ту біорес. і природокор. України. - 2010. - Випуск 154.1. [Електронний ресурс]. - Режим доступу : http://www.nbuv.gov.ua

2. Кобута I. В. Державна політика регулювання цін та аграрних ринків у 2009 р.: дотримання зобов’ язань перед СОТ / І. В. Кобута // Облік і фінанси АПК. - 2009. - № 4. - С. 170-176.

3. Лузан Ю. Я. Збалансованість попиту та пропозицій на продовольчому ринку України / Ю. Я. Лузан // Економіка АПК. - 2011. - № 8. - С. 27-36.

4. Нікішина О. В. Стратегічні орієнтири розвитку зернового ринку України / О. В. Нікішина. [Електронний ресурс]. - Режим доступу : http://www.confcontact.com.

5. Савенко I. I. Логістичний підхід в управлінні потоками зернозберігаючих підприємств. Теоретикоправовий та методологічний аспекти / I .І. Савенко : Наукове видання. - Одеса : Свротойз, 2008. - 272 с.

6. Савенко I. I. Перспективні напрями інноваційної діяльності зернозберігаючих підприємств / I. I. Савенко : Наук. вид. - Одеса : Поліграф, 2009. - 200 с.

7. Зерновой рынок : вызовы сезона - 2014/15 \& уроки 2013/14. // АПК-ИНФОРМ. - 2014. - № 1. - С. 8 14.

8. Зерна достатньо. Загрози продовольчій безпеці немає // АГРОПРОФІ. Український тижневик ділової інформації. [Електронний ресурс]. - Режим доступу : http://www.agroprofi.com.ua/index.

9. СПЕЦ-РЕЛИЗ : Возрождение судоходства на Днепре - проблемные вопросы на внутренних водных путях Украины. [Електронний ресурс]. - Режим доступу : http://ukragrocom.com.

10. http://dic.academic.ru/dic.nsf/econ_dict/5254. ниць України.

11. Постанова Кабінету Міністрів України від 6 квітня 1998 р. № 457. Про затвердження Статуту заліз-

12. Наказ Міністерства інфраструктури України від 09.11.2012 р. № 665 «Про затвердження Порядку видачі одноразових тимчасових дозволів на захід до річкових портів України суднам під прапорами держав, 3 якими не укладено міжнародні договори про судноплавство на внутрішніх водних шляхах»

13. Постанова Кабінету Міністрів України від 15.04.2009 р. № 350 «Про затвердження розмірів плати за проходження суден шлюзами Дніпровського каскаду» // Офіційний вісник України, 2009 р. - № 8. 


\author{
Седикова И.А. \\ кандидат экономических наук, доцент \\ кафедра менеджмента и логистики \\ Одесская национальная академия пищевых технологий \\ ул. Канатная, 112, г. Одесса, Украина, 65039 \\ E-mail: irina-sedikova@rambler.ru
}

\title{
УСЛОВИЯ ЭКСПОРТА ЗЕРНОВЫХ ГРУЗОВ УКРАИНЫ В НОВЫХ РЕАЛИЯХ
}

\begin{abstract}
Отечественный агросектор со значительными экспортным потенциалом может стать двигателем развития национальной экономики, предоставляя импульс инвестиционному, технологическому и социальному подъему Украины. Украина доказывает, что готова, несмотря на то, что происходит в стране, выполнять взятые на себя перед международными партнерами обязательства. Готовности инфраструктуры зернового рынка Украины обеспечивать растущие объемы экспорта сельхозпродукции и вызовам современности посвящено данное исследование.

В последнее десятилетие доля экспортируемого зерна выросла с 27\% в 2004/05 МГ до 52\% от общего объема производства зерна. Это позволяет констатировать экспортную ориентацию украинского зернового рынка, при которой из 63 млн. тонн произведенного в 2013 году зерна около 32,5 млн. тонн было экспортировано. Именно этот рекордный объем позволил Украине замкнуть тройку лидеров среди мировых экспортеров зерновых в прошлом сезоне.

Одним из отличительных фрактов сезона 2014 стало изменение зерновой логистики Украины за счет аннексии Крыма. Безусловно, главным вызовом современности является перенаправление грузовых потоков зерна из портов Крыма в порты материковой Украины. Решение проблем портов Азовского моря, в частности осложнения прохода судов через Керченский пролив, могут способствовать развитию портовой инфраструктуры ОдесскоДунайского региона, возможно строительство речных терминалов в портах Черного моря в случае переформатирования логистических потоков украинских зерновых грузов.

Проведенное исследование развития и проблем речного судоходства позволило сделать такие выводы и предложения: для возрождения судоходства необходимы законодательные изменения, которые смогут подтолкнуть развитие внутренней водной инфраструктуры, привести тарифную нагрузку государства на речные перевозки до экономически обоснованного уровня, создать равные конкурентные условия для работы на речном транспорте; сравнить правовой статус и экономические условия судна под украинским и иностранным фрлагами при работе на внутренних водных путях; снизить тарифное давление на перевозчиков путем уравнивания размера портовых сборов для иностранных рейсов до уровня каботажных рейсов, а также снижения ставок портовых сборов.

На данный момент, неопределенность правого статуса портов, терминалов, земель речного транспорта, гидротехнических сооружений, прав и обязанностей перевозчиков, порта и грузовладельца нивелирует инвестиционную привлекательность речного транспорта.
\end{abstract}

Ключевые слова: зерновой рынок, экспорт, зерновая логистика, водные пути, морские и речные порты.

Sedikova I.A.

$\mathrm{PhD}$ in Economics, Associate Professor

Department of Management and Logistics

Odessa National Academy of Food Technologies

Kanatnaya Str., 112, Odessa, Ukraine, 65039

E-mail: irina-sedikova@rambler.ru

\section{TERMS OF EXPORTS GRAIN CARGOES UKRAINE IN THE NEW REALITIES}

The domestic agricultural sector with significant export potential can become the driving force of the national economy, giving impetus to investment, technological and social recovery Ukraine. Ukraine argues that it is ready, despite taking place in the country to fulfill its obligations to international partners. Readiness infrastructure grain market of Ukraine to increasing exports of agricultural products and the challenges of today is dedicated to this study. Since the 
last decade, the share of exported grain increased from $27 \%$ in 2004/05 marketing year to $52 \%$ of total grain production. It reveals that export orientation of Ukrainian grain market in which $63 \mathrm{mln}$. tons produced in 2013 grain about 32.5 million tons were exported. This is the record amount allowed Ukraine to close three of the leading world exporters of grain last season. One of the distinctive fact of season 2014 was the change in grain logistics Ukraine due to the annexation of the Crimea. Of course, the main challenge is the redirection of grain cargo flows from the ports of Crimea in Ukraine mainland ports. Addressing the Azov Sea ports, including complications passage of vessels through the Strait of Kerch, could contribute to Odessa and port infrastructure in the Danube region, possible construction of river terminals in Black Sea ports when reformatting logistics flows Ukrainian grain cargoes. The research and development problems of river navigation allowed to make the following conclusions and recommendations: to revive the shipping necessary legislative changes that will encourage the development of inland waterway infrastructure, bring tariff burden on state river transport to economic levels, create equal competitive conditions for the river transport; compare the legal status and economic condition of the vessel under Ukrainian and foreign flags when working on inland waterways; reduce tariff pressure on carriers by size equalization port charges for international flights to level coastal voyages, as well as lower rates of port charges. Currently, the uncertainty of legal status of ports, terminals, land river transport, waterworks, rights and obligations of carriers and cargo port eliminates the investment attractiveness of maritime transport.

Keywords: grain market, export, grain logistics, waterways, sea and river ports.

\section{References}

1. Bodnar O. V. (2010). Formuvannia tsinovykh tendentsii na zernovomu rynku Ukrainy. Nauk. visn. Nats. un-tu biores. i pryrodokor. Ukrainy. Vypusk 154.1. [Elektronnyi resurs]. Rezhym dostupu : http://www.nbuv.gov.ua

2. Kobuta I. V. (2009). Derzhavna polityka rehuliuvannia tsin ta ahrarnykh rynkiv u 2009 r.: dotrymannia zoboviazan pered SOT. Oblik i finansy APK. № 4, 170-176.

3. Luzan Yu. Ya. (2011). Zbalansovanist popytu ta propozytsii na prodovolchomu rynku Ukrayiny. Ekonomika APK. № 8, 27-36.

4. Nikishyna O. V. Stratehichni oriientyry rozvytku zernovoho rynku Ukrainy. [Elektronnyi resurs]. Rezhym dostupu : http://www.confcontact.com.

5. Savenko I. I. (2008). Lohistychnyi pidkhid v upravlinni potokamy zernozberihaiuchykh pidpryyemstv. Teoretyko-pravovyi ta metodolohichnyi aspekty. I .I. Savenko : Naukove vydannia. Odesa : Yevrotoiz, 272.

6. Savenko I. I. (2009). Perspektyvni napriamy innovatsiinoi diialnosti zernozberihaiuchykh pidpryiemstv. I. I. Savenko : Nauk. vyd. Odesa : Polihraf, 200.

7. Zernovoi rynok: vyzovy sezona - 2014/15 \& uroky 2013/14. (2014). APK-YNFORM. № 1, 8-14.

8. Zerna dostatno. Zahrozy prodovolchii bezpetsi nemaie. AHROPROFI. Ukrainskyi tyzhnevyk dilovoi informatsii. [Elektronnyi resurs]. Rezhym dostupu : http://www.agroprofi.com.ua/index.

9. SPETs-RELYZ : Vozrozhdenye sudokhodstva na Dnepre - problemnye voprose na vnutrennykh vodnykh putiakh Ukrayny. [Elektronnyi resurs]. Rezhym dostupu : http://ukragrocom.com.

10. http://dic.academic.ru/dic.nsf/econ_dict/5254.

11. Postanova Kabinetu Ministriv Ukrainy vid 6 kvitnia 1998 r. № 457. Pro zatverdzhennia Statutu zaliznyts Ukrainy.

12. Nakaz Ministerstva infrastruktury Ukrainy vid 09.11.2012 r. № 665 «Pro zatverdzhennia Poriadku vydachi odnorazovykh tymchasovykh dozvoliv na zakhid do richkovykh portiv Ukrainy sudnam pid praporamy derzhav, $\mathrm{z}$ yakymy ne ukladeno mizhnarodni dohovory pro sudnoplavstvo na vnutrishnikh vodnykh shliakhakh»

13. Postanova Kabinetu Ministriv Ukrainy vid 15.04.2009 r. № 350 «Pro zatverdzhennia rozmiriv platy za prokhodzhennia suden shliuzamy Dniprovskoho kaskadu». Ofitsiinyi visnyk Ukrainy, 2009 r. № 8. 